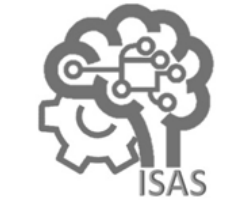
JOURNAL OF APPLIED CIVIL ENGINEERING AND INFRASTRUCTURE TECHNOLOGY (JACEIT)

Vol. 1 No. 2 (2020) 23 - 28

ISSN Media Elektronik: 2723-5378

\title{
Pengaruh Penggunaan Pasir Puger Sebagai Agregat Halus Terhadap Karakteristik (LASTON AC-WC)
}

\author{
Hamdani Nugroho ${ }^{1}$, Mirza Gulam Rifqi ${ }^{2}$, dan M. Shofiul Amin ${ }^{3}$ \\ ${ }^{1}$ Jurusan Teknik Sipil, Politeknik Negeri Banyuwangi \\ ${ }^{2}$ Jurusan Teknik Sipil, Politeknik Negeri Banyuwangi \\ ${ }^{3}$ Jurusan Teknik Sipil, Politeknik Negeri Banyuwangi \\ ${ }^{1}$ hamjay777@gmail.com*, ${ }^{2}$ mirza@poliwangi.ac.id, ${ }^{3}$ shofiul@ poliwangi.ac.id
}

\begin{abstract}
Asphalt concrete is a layer in the construction of highway pavement consisting of fine aggregate, coarse aggregate, filler, and asphalt. asphalt has several advantages compared to other materials. Therefore concrete asphalt is widely used and its needs have increased. To complement these needs, research is conducted as an alternative that is using Puger sand as fine aggregate. Puger sand is natural sand containing iron ore of approximately $49.7 \%$ and has a reserve of concentrate of approximately 700,000 tons. The purpose of this research was to determine the use of Puger sand as fine aggregate on the characteristics of Laston AC-WC. This study uses 5 variations including 100\%, 75\%, 50\%, 25\% and 0\% Puger sand mixture and using asphalt content of 5\%, 5.5\%, 6\%, 6.5\% and $7 \%$. Marshall test results that have been done produce an optimum asphalt content of $5.5 \%$ with a variation of the use of a 50\% Puger sand mixture. Obtained stability $1763.54 \mathrm{~kg}$, Flow $3.7 \mathrm{~mm}, \mathrm{MQ} 474.5 \mathrm{~kg} / \mathrm{mm}$, VIM $4.14 \%$, VMA $15.2 \%$, and VFB of $72.46 \%$. So that the use of Puger sand as fine aggregate can complement the Bina Marga General Specifications 2018.
\end{abstract}

Keywords: laston, asphalt, Puger sand, aggregate, filler, iron ore.

\begin{abstract}
Abstrak
Aspal beton merupakan suatu lapisan pada konstruksi perkerasan jalan raya yang terdiri dari agregat halus, agregat kasar, filler, dan aspal. Aspal beton sendiri mempunyai beberapa kelebihan dibandingkan dengan bahan-bahan lain. Oleh sebab itu aspal beton banyak digunakan dan kebutuhannya mengalami peningkatan, untuk memenuhi kebutuhan tersebut dilakukan penelitian Sebagai alternatif lain yaitu menggunakan pasir Puger sebagai agregat halus. Pasir puger merupakan pasir alam yang mengandung biji besi sekitar $49,7 \%$ dan memiliki cadangan konsentrat sekitar sebesar 700.000 Ton. Tujuan penelitian ini untuk mengetahui penggunaan pasir puger sebagai agregat halus terhadap karakteristik Laston AC-WC. Dari penelitian ini menggunakan 5 variasi yaitu $100 \%, 75 \%$, $50 \%, 25 \%$ dan $0 \%$ campuran pasir puger dan menggunakan kadar aspal 5\%, 5,5\%,6\%, 6,5\% dan 7\%. Hasil uji Marshall yang telah dilakukan diperoleh Kadar Aspal Optimum sebesar 5,5\% dengan variasi penggunaan campuran pasir Puger 50\%, dengan diperoleh Stabilitas 1763,54 kg, Flow 3,7 mm, MQ 474,5 kg/mm, VIM 4,14\%, $V M A 15,2 \%$, dan $V F B$ sebesar $72,46 \%$. Sehingga penggunaan pasir Puger sebagai agregat halus dapat memenuhi Spesifikasi Umum Bina Marga 2018.
\end{abstract}

Kata kunci: laston, aspal, pasir Puger, agregat, filler, biji besi.

Diterima Redaksi : 08-11-2020 | Selesai Revisi : 18-11-2020 | Diterbitkan Online : 04-12-2020

\section{Pendahuluan}

Aspal beton merupakan suatu lapisan pada konstruksi perkerasan jalan raya yang terdiri dari agregat halus, agregat kasar, filler, dan aspal. Agregat halus yang digunakan sebagai campuran aspal pada umumnya merupakan pasir alam yang berasal dari sungai. Aspal beton sendiri mempunyai beberapa kelebihan dibandingkan dengan bahan-bahan lain. Oleh sebab itu aspal beton banyak digunakan sehingga kebutuhan akan bahan dasar campuran yang dibutuhkan dalam skala besar, untuk memenuhi kebutuhan tersebut maka harus 
mencari alternatif lain dengan memanfaatkan sumber daya alam sekitar.

Sebagai alternatif lain dengan pemanfaatan sumber daya alam yang akan digunakan untuk penelitian ini yaitu menggunakan pasir Puger sebagai agregat halus. Pasir puger didapatkan dari hasil tambang bukit pasir yang berada di kawasan pesisir Pantai Desa Nyamplong Kobong, Puger, Jember, Jawa Timur. Pasir puger memiliki sifat fisik yang berwarna hitam dan cenderung halus. Pasir puger merupakan pasir alam yang mengandung biji besi sekitar 49,7 \% dan memiliki cadangan konsentrat sebanyak sebesar 700.000 Ton.

Pasir yang terdapat kandungan biji besi atau pasir besi dapat memenuhi persyaratan untuk digunakan sebagai agregat halus yang digunakan dalam campuran aspal beton lapisan aus AC-WC [1]. Dan karakteristik volumetrik campurannya menunjukkan bahwa penggunaan pasir besi sebagai agregat halus dapat menurunkan rongga antar agregat dalam campuran dan dapat meningkatkan nilai rongga terisi dalam campuran aspal [2].

Namun penggunaan pasir Puger sebagai agregat halus perlu dilakukan penelitian lebih lanjut untuk mengetahui kadar optimum campuran pasir Puger dalam campuran aspal beton AC-WC. Dengan penelitian ini diharapkan pasir Puger dapat menjadi alternatif pengganti agregat halus yang berasal dari sungai dan dapat mengetahui pengaruh penggunaan pasir Puger terhadap campuran Laston AC-WC.

\section{Metode Penelitian}

Penelitian ini dilakukan di Laboratorium Uji Bahan Jalan Teknik Sipil Politeknik Negeri Banyuwangi. Penelitian yang dilakukan yaitu dengan penggunaan pasir puger sebagai agregat halus dan menggunakan aspal penetrasi 60/70 yang mengacu pada Spesifikasi Umum Bina Marga 2018. Langkah-langkah pelaksanaan penelitian menggunakan Metode Marshall yang dilakukan pada penelitian ini adalah sebagai berikut:

2.1 Studi pustaka

2.2 Persiapan alat dan bahan

2.3 Pengujian material

2.4 Rancangan campuran

2.5 Penetuan Kadar Aspal Optimum KAO

2.6 Pembuatan benda uji

2.7 Pengujian marshall

2.8 Analisa dan pembahasan

2.9 Kesimpulan dan saran

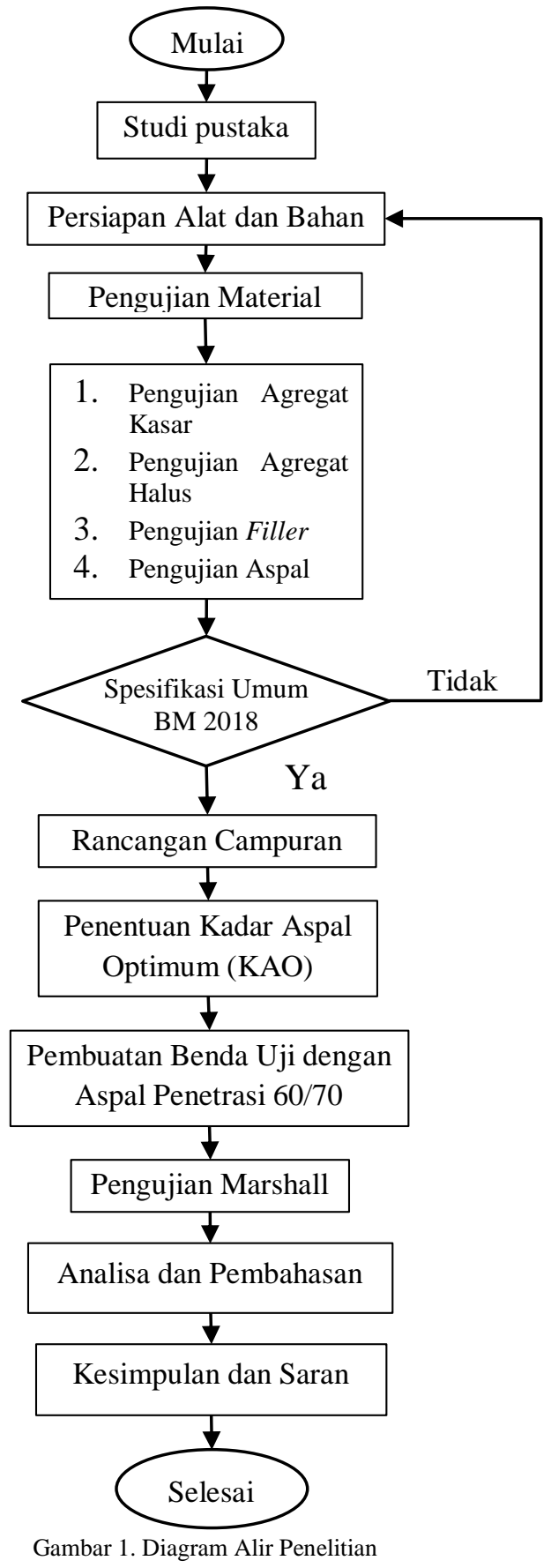

\section{Hasil dan Pembahasan}

\subsection{Hasil Pengujian Agregat dan Aspal}

Pengujian agregat yang dilakukan pada penelitian ini diantaranya pengujian berat jenis agregat, pengujian lolos saringan No. 200, pengujian impact, pengujian Los Angeles, pengujian analisa saringan, dan pengujian berat jenis filler. Sedangkan pengujian aspal yang dilakukan yaitu pengujian titik nyala, pengujian titik lembek, pengujian daktilitas, pengujian berat jenis aspal. Dari semua pengujian yang telah dilakukan telah memenuhi Spesifikasi Umum Bina Marga 2018. 


\subsection{Stabilitas}

Stabilitas merupakan kemampuan lapis perkerasan menerima beban lalu lintas tanpa terjadi perubahan bentuk tetap [4]. Kebutuhan akan stabilitas setingkat dengan jumlah beban lalu lintas yang melalui jalan tersebut. Parameter-parameter yang diperlukan dan diperoleh dari pengujian marshall, dalam pengujian stabilitas benda dikondisikan dalam keadaan panas $\pm 60^{\circ}$ $\mathrm{C}$ yang dinyatakan dalam $(\mathrm{kg})$. Untuk hasil rekapitulasi nilai stabilitas dapat dilihat pada Tabel 1

Tabel 1. Rekapitulasi Nilai Stabilitas

\begin{tabular}{|c|c|c|c|c|c|}
\hline \multicolumn{6}{|c|}{ NILAI STABILITAS HASIL PENGUJIAN } \\
\hline Macam & STABILITAS & STABILITAS & STABILITAS & STABILITAS & STABILITAS \\
\hline Campuran & pp 100 : pl $0 \%$ & pp 75 : pl 25\% & pp 50: pl 50\% & pp 25: pl 75\% & pp $0:$ pl $100 \%$ \\
\hline $5.0 \%$ & 2586.03 & 2434.13 & 2085.86 & 1759.83 & 2774.98 \\
\hline $5.5 \%$ & 1611.64 & 1519.01 & 1763.54 & 1548.65 & 1945.08 \\
\hline $6.0 \%$ & 1278.19 & 1281.16 & 1363.41 & 1430.10 & 1715.37 \\
\hline $6.5 \%$ & 1241.14 & 1141.11 & 1270.78 & 1359.70 & 1544.95 \\
\hline $7.0 \%$ & 1051.43 & 981.80 & 1141.11 & 1311.54 & 1304.13 \\
\hline Spesifikasi & $>800$ & $>800$ & $>800$ & $>800$ & $>800$ \\
\hline BM 2018 & $>800$ & $>800$ & $>800$ & 2000 & 3000 \\
\hline
\end{tabular}

Dari hasil nilai pengujian stabilitas yang terdapat pada Tabel 1 selanjutnya data tersebut dipaparkan dalam bentuk grafik yang dapat dilihat pada Gambar 2.

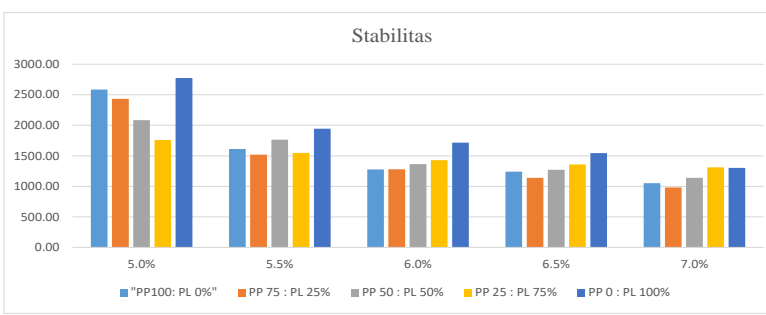

Gambar 2. Grafik Rekapitulasi Nilai Stabilitas

Dari Gambar 2 dapat dilihat bahwa nilai rekapitulasi stabilitas pada masing- masing variasi kadar aspal sesuai dengan nilai yang diisyaratkan yang terdapat pada [3] yaitu dapat menahan beban minimum $800 \mathrm{Kg}$.

\subsection{Flow}

Flow merupakan Jumlah perubahan bentuk (deformasi) yang diukur dalam satuan millimeter yang ditunjukkan Flow menunjukkan tingkat kelenturan suatu campuran. Nilai flow dipengaruhi oleh dipaparkan dalam bentuk grafik yang dapat dilihat pada gradasi agregat dan proses pemadatan dalam sebuah Gambar 4.

campuran aspal. Untuk hasil rekapitulasi nilai flow dapat dilihat pada Tabel 2

Tabel 2. Rekapitulasi Nilai Flow

\begin{tabular}{|c|c|c|c|c|c|}
\hline \multicolumn{7}{|c|}{ NILAI FLOW/ KELELEHAN HASIL PENGUJIAN } \\
\hline \multirow{2}{*}{ Macam Campuran } & Flow & Flow & Flow & Flow & Flow \\
\cline { 2 - 7 } & pp 100: pl 0\% & pp 75: pl 25\% & pp 50: pl 50\% & pp 25: pl 75\% & pp 0: pl 100\% \\
\hline $5.0 \%$ & 3.9 & 3.8 & 3.7 & 3.3 & 3.2 \\
\hline $5.5 \%$ & 3.9 & 4.0 & 3.7 & 3.6 & 3.5 \\
\hline $6.0 \%$ & 4.2 & 4.1 & 4.0 & 4.1 & 3.8 \\
\hline $6.5 \%$ & 4.9 & 4.8 & 4.5 & 4.7 & 4.6 \\
\hline $7.0 \%$ & 5.3 & 5.2 & 5.0 & 5.1 & 4.9 \\
\hline Spesifikasi min & $\mathbf{2}$ & $\mathbf{2}$ & $\mathbf{2}$ & $\mathbf{2}$ & $\mathbf{2}$ \\
\hline BM 2018 max & $\mathbf{4}$ & $\mathbf{4}$ & $\mathbf{4}$ & $\mathbf{4}$ & $\mathbf{4}$ \\
\hline
\end{tabular}

Dari hasil nilai pengujian stabilitas yang terdapat pada Tabel 2 selanjutnya data pengujian tersebut dipaparkan dalam bentuk grafik yang dapat dilihat pada Gambar 3 .

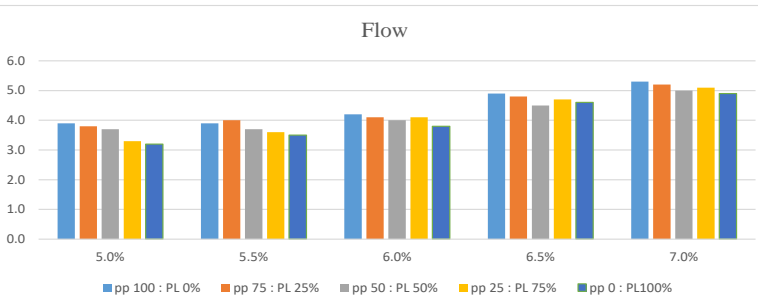

Gambar 3. Grafik Rekapitulasi Nilai Flow

Berdasarkan Gambar 3 dapat dilihat bahwa nilai flow mengalami peningkatan dari kadar aspal 5\% sampai dengan kadar aspal 7\%. Dari hasil pengujian untuk nilai flow pada kadar aspal 5\% dan 5,5\% diperoleh nilai yang dapat memenuhi syarat pada [3], untuk kadar aspal 6\% pada variasi PP 50\%: PL 50\% dan PP 0\%: PL 100\% saja yang dapat memenuhi syarat [3] yaitu $2-4 \mathrm{~mm}$. Sedangkan nilai flow pada kadar aspal 6,5\% dan 7\% diperoleh nilai yang melebihi batas maksimum yang sudah ditetapkan..

\subsection{Void In Mix (VIM)}

Rongga dalam campuran adalah volume total udara yang berada di antara partikel agregat yang terselimuti aspal dalam suatu campuran yang telah dipadatkan dan dinyatakan dalam persen volume bulk. Nilai VIM dipengaruhi oleh gradasi agrgegat, jumlah dan temperature pemadatan. Hasil rekapitulasi nilai rongga dalam campuran (VIM) dapat dilihat pada Tabel 3

Tabel 3. Rekapitulasi Nilai Rongga dalam Campuran

\begin{tabular}{|c|c|c|c|c|c|}
\hline \multicolumn{7}{|c|}{ NILAI VIM HASIL PENGUJIAN } \\
\hline \multirow{2}{*}{ Macam Campuran } & VIM & VIM & VIM & VIM & VIM \\
\cline { 2 - 6 } & pp 100: pl 0\% & pp 75: pl 25\% & pp 50: pl 50\% & pp 25: pl 75\% & pp 0: pl 100\% \\
\hline $5.0 \%$ & 5.03 & 5.14 & 5.20 & 5.63 & 5.69 \\
\hline $5.5 \%$ & 3.50 & 4.13 & 4.14 & 4.98 & 5.35 \\
\hline $6.0 \%$ & 3.86 & 3.79 & 3.87 & 4.40 & 5.17 \\
\hline $6.5 \%$ & 3.09 & 4.03 & 3.24 & 3.69 & 4.61 \\
\hline $7.0 \%$ & 3.56 & 3.53 & 3.11 & 3.05 & 3.51 \\
\hline Spesifikasi BM 2018 & $\mathbf{5 - 3}$ & $\mathbf{5 - 3}$ & $\mathbf{5 - 3}$ & $\mathbf{5 - 3}$ & $\mathbf{5 - 3}$ \\
\hline
\end{tabular}

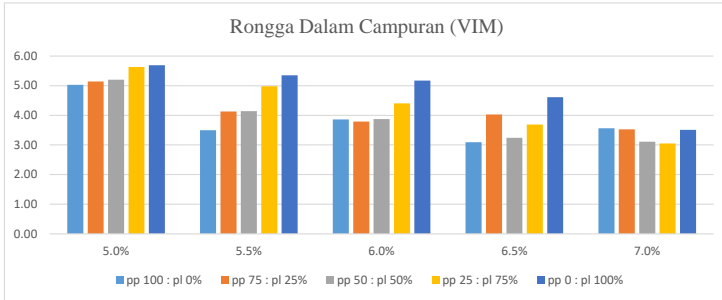

Gambar 4. Grafik Rekapitulasi Nilai VIM

BerdasarkanError! Reference source not found. Gambar 4 dapat dilihat bahwa nilai rongga dalam campuran (VIM) mengalami penurunan dari kadar aspal 5\% sampai 
dengan kadar aspal 7\%. Dari hasil pengujian untuk nilai antara agregat dalam campuran. VMA yang kecil VIM pada kadar aspal 6,5\% dan 7\% diperoleh nilai yang menyebabkan aspal menyelimuti agregat secara terbatas, dapat memenuhi syarat pada [3], untuk kadar aspal 5,5\% sehingga menyebabkan mudah terjadinya kerusakan.. dan 6\% pada variasi PP $0 \%$ : PL 100\% saja yang tidak dapat memenuhi syarat [3] yaitu 3 - 5. Sedangkan nilai 3.6 Rongga Terisi Aspal (VFB)

VIM pada kadar aspal 5\% untuk semua variasi diperoleh nilai yang melebibi dari batas maksimum yang sudah ditetapkan. Nilai VIM terus menurun dengan bertambahnya kadar aspal, hal ini menunjukkan bahwa kadar aspal sangat berpengaruh terhadap rongga dalam campuran.

\subsection{Rongga Dalam Agregat (VMA)}

Rongga terisi aspal adalah persentase rongga terisi aspal pada campuran setelah mengalami proses pemadatan. Nilai $V F B$ dipengaruhi oleh jumlah dan temperature pemadatan, gradasi agregat dan kadar aspal. Nilai $V F B$ yang terlalu rendah akan mengurangi keawetan suatu campuran aspal sedangkan nilai $V F B$ yang terlalu tinggi campuran aspal mudah mengalami bleeding karena rongga dalam campuran tidak tersedia atau terlalu kecil

Rongga dalam agregat adalah rongga antar butiran yang menyebabkan aspal naik ke permukaan. Hasil agregat dalam campuran aspal yang sudah dipadatkan rekapitulasi nilai rongga terisi aspal ( $V F B$ ) dapat dilihat serta aspal efektif yang dinyatakan dalam persentase pada Tabel 5

volume total campuran. Nilai VMA dipengaruhi oleh faktor pemadatan yaitu jumlah tumbukan dan temperature pemadatan. Hasil rekapitulasi nilai rongga dalam agregat (VMA) dapat dilihat padaTabel 4

Tabel 4. Rekapitulasi Nilai Rongga dalam Agregat

\begin{tabular}{|c|c|c|c|c|c|}
\hline \multirow{2}{*}{$\begin{array}{c}\text { Macam } \\
\text { Campuran }\end{array}$} & VMA & VMA & VMA & VMA & VMA \\
\hline & pp 100 : pl 0\% & pp 75 : pl 25\% & pp 50 : pl $50 \%$ & pp 25 : pl 75\% & pp 0 : pl 100\% \\
\hline $5.0 \%$ & 14.62 & 14.76 & 14.83 & 15.21 & 15.27 \\
\hline $5.5 \%$ & 14.34 & 15.01 & 15.02 & 15.76 & 16.09 \\
\hline $6.0 \%$ & 15.83 & 15.83 & 15.90 & 16.37 & 17.04 \\
\hline $6.5 \%$ & 16.27 & 17.15 & 16.47 & 16.86 & 17.66 \\
\hline $7.0 \%$ & 17.77 & 17.82 & 17.47 & 17.41 & 17.80 \\
\hline $\begin{array}{c}\text { Spesifikasi } \\
\text { BM } 2018\end{array}$ & $>15$ & $>15$ & $>15$ & $>15$ & $>15$ \\
\hline
\end{tabular}

Tabel 5. Rekapitulasi Nilai Rongga Terisi Aspal (VFB)

\begin{tabular}{|c|c|c|c|c|c|}
\hline \multicolumn{7}{|c|}{ NILAI VFA HASIL PENGUJIAN } \\
\hline \multirow{2}{*}{ Macam Campuran } & VFA/VFB & VFA/VFB & VFA/VFB & VFA/VFB & VFA/VFB \\
\cline { 2 - 6 } & pp 100: pl 0\% & pp 75: pl 25\% & pp 50: pl 50\% & pp 25: p1 75\% & pp 0: pl 100\% \\
\hline $5.0 \%$ & 65.60 & 65.19 & 64.95 & 63.00 & 62.71 \\
\hline $5.5 \%$ & 75.64 & 72.46 & 72.46 & 68.39 & 66.75 \\
\hline $6.0 \%$ & 75.62 & 76.08 & 75.69 & 73.11 & 69.65 \\
\hline $6.5 \%$ & 80.98 & 76.50 & 80.35 & 78.10 & 73.87 \\
\hline $7.0 \%$ & 79.96 & 80.19 & 82.19 & 82.49 & 80.31 \\
\hline Spesifikasi & $>65$ & $>65$ & $>65$ & $>65$ & $>65$ \\
\hline BM 2018 & $>65$ & &
\end{tabular}

Dari pengujian rongga terisi aspal ( $V F B$ ) yang terdapat pada Tabel 5 selanjutnya data tersebut dipaparkan dalam bentuk grafik yang dapat dilihat pada Gambar 6 .

Dari pengujian rongga dalam agregat (VMA) yang terdapat pada Tabel 4 selanjutnya data tersebut dipaparkan dalam bentuk grafik yang dapat dilihat pada Gambar 5.

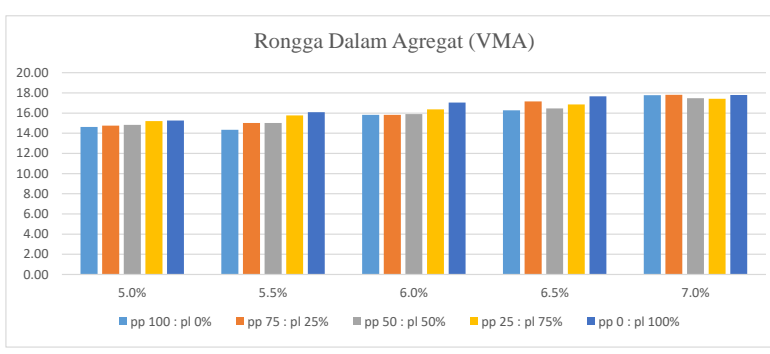

Gambar 5. Grafik Rekapitulasi Nilai VMA

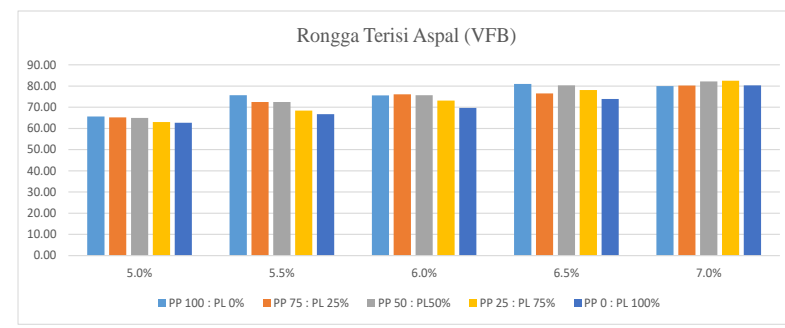

Gambar 6. Grafik Rekapitulasi Nilai VFB

Berdasarkan Gambar 6 dapat dilihat bahwa nilai rongga terisi aspal $(V F B)$ mengalami peningkatan dari kadar aspal 5\% sampai dengan kadar aspal 7\% dari hasil tersebut untuk nilai rongga terisi aspal ( VFB) pada kadar aspaal 5,5\% - 7\% sudah sesuai dengan nilai yang diisyaratkan yang terdapat pada [3] yaitu minimum 65\%, Berdasarkan Gambar 5 dapat dilihat bahwa nilai rongga sedangkan untuk kadar aspal 5\% pada variasi PP $100 \%$ dalam agregat (VMA) mengalami peningkatan darikadar : PL 0\% dan PP 75\% : PL 25\% saja yang dapat aspal 5\% sampai dengan kadar aspal 7\%. Dari hasil memenuhi syarat [3]. Peningkatan nilai VFB yang terus pengujian untuk nilai VMA pada kadar aspal 6\% - 7\% meningkat seiring dengan bertambahnya kadar aspal diperoleh nilai yang dapat memenuhi syarat pada [3], dalam campuran. Hal ini disebabkan rongga dalam untuk kadar aspal 5.5\% pada variasi PP 100\% : PL 0\% campuran mengecil karena bertambahnya aspal yang saja yang tidak dapat memenuhi syarat [3] yaitu meresap dan menyelimuti butiran agregat. minimum $15 \%$. Sedangkan nilai $V M A$ pada kadar aspal 5\% untuk variasi PP 25\% : PL 75\% dan PP 0\%: PL 3.7 Marshall Quotient (MQ)

$100 \%$ saja yang dapat memenuhi syarat [3]. Nilai VMA semakin meningkat dengan penambahan kadar aspal, karena dengan kadar aspal yang semakin banyak semakin besar pula rongga-rongga udara yang tertutup oleh aspal tersebut, sehingga terjadi ikatan yang kuat

Nilai Marshall Quotient (MQ) merupakan indeks kelenturan suatu campuran berupa perbandingan antara stabilitas terhadap flow dengan satuan $\mathrm{kg} / \mathrm{mm}$. Nilai MQ ini dihubungkan dengan daya tahan perkerasan terhadap

Journal of Applied Civil Engineering and Infrastructure Technology (JACEIT) 
deformasi. Semakin besar nilai MQ menandakan campuran semakin kaku/getas sehingga dapat terjadi retak apabila diberi beban, sedangkan semakin kecil nilai MQ menandakan campuran semakin lentur. Hasil rekapitulasi nilai Marshall Quotient dapat dilihat pada Tabel 6

Tabel 6. Rekapitulasi Nilai MQ

\begin{tabular}{|c|c|c|c|c|c|}
\hline \multicolumn{7}{|c|}{ NILAI VMA HASIL PENGUJIAN } \\
\hline \multirow{2}{*}{$\begin{array}{c}\text { Macam } \\
\text { Campuran }\end{array}$} & VMA & VMA & VMA & VMA & VMA \\
\cline { 2 - 6 } & $\mathbf{p p ~ 1 0 0 : ~ p l ~ 0 \% ~}$ & pp 75: pl 25\% & pp 50: pl 50\% & pp 25: pl 75\% & pp 0: pl 100\% \\
\hline $5.0 \%$ & 14.62 & 14.76 & 14.83 & 15.21 & 15.27 \\
\hline $5.5 \%$ & 14.34 & 15.01 & 15.02 & 15.76 & 16.09 \\
\hline $6.0 \%$ & 15.83 & 15.83 & 15.90 & 16.37 & 17.04 \\
\hline $6.5 \%$ & 16.27 & 17.15 & 16.47 & 16.86 & 17.66 \\
\hline $7.0 \%$ & 17.77 & 17.82 & 17.47 & 17.41 & 17.80 \\
\cline { 1 - 6 } Spesifikasi & $>15$ & $>15$ & $>15$ & $>15$ & $>15$ \\
\hline BM 2018 & $>15$ & & & \\
\hline
\end{tabular}

Hasil pengujian Marshall Quotient (MQ) yang terdapat pada Tabel 6 selanjutnya data tersebut dipaparkan dalam bentuk grafik yang dapat dilihat pada Gambar 7 .

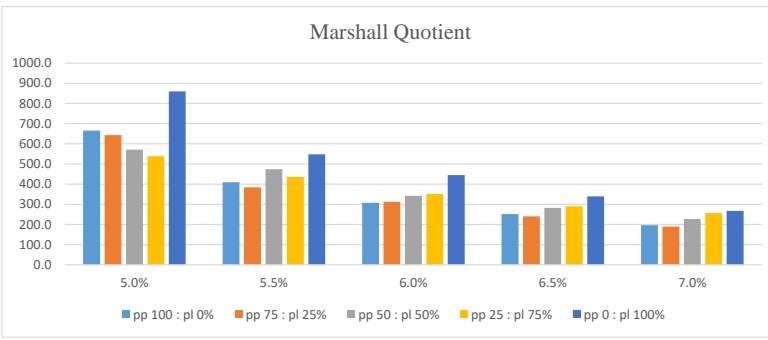

Gambar 7. Grafik Rekapitulasi Nilai MQ

Berdasarkan Gambar 7 dapat dilihat bahwa nilai Marshall Quotient (MQ) mengalami penurunan dari kadar aspal 5\% sampai dengan kadar aspal 7\%. Dari hasil pengujian untuk nilai $M Q$ pada kadar aspal 5\% - 6\% diperoleh nilai yang dapat memenuhi syarat pada [3] untuk kadar aspal 6,5\% pada variasi PP 75\% : PL 25\% saja yang tidak dapat memenuhi syarat [3] yaitu minimum $250 \mathrm{~kg} / \mathrm{mm}$. Sedangkan nilai $M Q$ pada kadar aspal $7 \%$ untuk semua variasi diperoleh nilai yang kurang dari batas minimum yang sudah ditetapkan.

\subsection{Kadar Aspal Optimum (KAO)}

Kadar Aspal Optimum (KAO) adalah nilai tengah dari rentang kadar aspal yang menggambarkan hubungan antara kadar aspal rancangan dengan nilai dari setiap parameter karakteristik Marshall dan yang memenuhi sifat-sifat campuran serta ketentuan yang disyaratkan. Penentuan kadar aspal optimum (KAO) bertujuan untuk mengetahui kadar aspal yang baik atau kadar aspal efektif pada campuran lapis aspal beton. Dari masingmasing grafik hubungan antara parameter pengujian Marshall dengan variasi kadar aspal 5\%, 5,5\%, 6\%, $6,5 \%$ dan $7 \%$ diperoleh nilai kadar aspal optimum yang dapat dilihat pada Gambar 8.

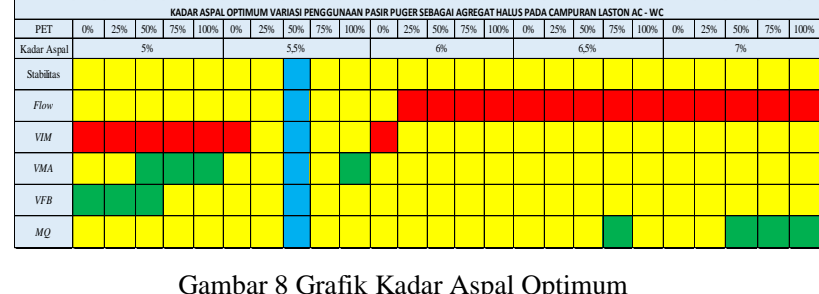

Gambar 8 Grafik Kadar Aspal Optimum

Berdasarkan Gambar 8 menunjukkan hubungan parameter Marshall dengan kadar aspal pada penggunaan variasi pasir Puger sebagai agregat halus diperoleh kadar aspal optimum yaitu 5,5\% dengan variasi penggunaan pasir Puger 50\% : pasir Lumajang $50 \%$. Dari hasil tersebut maka dapat diartikan bahwa kadar aspal yang baik digunakan dalam campuran lapis aspal beton dengan menggunakan pasir puger adalah 5,5\% variasi pasir Puger 50\% : pasir Lumajang 50\% untuk nilai parameter marshallnya sudah sesuai dengan [3].

\section{Kesimpulan}

Dari hasil penelitian yang telah dilakukan pada campuran Laston AC-WC dengan menggunakan campuran pasir Puger sebagai agregat halus diperoleh beberapa kesimpulan yaitu :

1. Penggunaan pasir puger sebagai agregat halus pada campuran Laston AC-WC didapatkan nilai Kadar Aspal Optimum (KAO) yaitu pada $(\mathrm{Pb})$ sebesar $5.5 \%$ variasi pasir Puger 50\% : pasir Lumajang $50 \%$ dengan nilai Stabilitas 1.763,54 kg, Flow 3,7 $\mathrm{mm}$, Rongga dalam campuran (VIM) 4,14\%, rongga dalam agregat (VMA) 15,02\%, rongga dalam aspal (VFB) 72,46\%, dan Marshall Qoutient (MQ) 474,5kg/mm yang sudah memenuhi Spesifikasi Umum Bina Marga 2018.

2. Semakin banyaknya penambahan kadar pasir Puger dan kadar aspal nilai stabilitas mengalami penurunan dikarenakan penambahan pasir puger dan kadar aspal menyebabkan kelelehan yang cukup tinggi sehingga nilai Flownya mengalami peningkatan. Namun adanya penambahan pasir puger menurunkan nilai VIM dan VMA dikarenakan penambahan pasir Puger dapat menutup pori agregat dan daya ikat antar agregat lebih kuat sehingga campuran bersifat kedap air. Sedangkan, nilai $V F B / V F A$ mengalami peningkatan dan hasil bagi Marshall atau Marshall Quotient (MQ) cenderung mengalami penurunan dengan bertambahnya kadar aspal dan kadar pasir Puger Dari hasil penelitian yang telah dilakukan ada beberapa hal yang dapat disarankan untuk dilanjutkan dengan mengkombinasikan penggunaan pasir pasir Puger sebagai agregat halus dengan kombinasi dan komposisi campuran tertentu lainya yang dapat meningkatkan hasil pengujin Marshall. 


\section{Daftar Rujukan}

[1]. Hamid Aly, S., \& Takdir, T. 2011. Penggunaan Pasir Besi Sebagai Agregat Halus Pada Beton Aspal Lapisan Aus. Jurnal Transportasi, 123-134.

[2]. Pusat Sumber Daya Geologi. 2014. Pasir Besi Di Indonesia Geologi, Eksplorasi dan Pemanfaatnya. Bandung: Kementrian Energi dan Sumber Daya Mineral.

[3]. Spesifikasi Umum Bina Marga. 2018. Divisi 6.3 Campuran Beraspal Panas. Jawa Timur: Badan Standartrisasi Nasional.

[4]. Sukirman, S. 2010. Perencanaan Tebal Struktur Perkerasan Lentur. Bandung: Nova. 